\title{
Occult phosphaturic mesenchymal tumour of femur cortex causing oncogenic osteomalacia - diagnostic challenges and clinical outcomes
}

\author{
Utajony fosfaturyczny guz mezenchymalny kory kości udowej powodujący \\ osteomalację onkogenną — problemy diagnostyczne i skutki kliniczne \\ Deep Dutta ${ }^{1}$, Raghuvansh Kumar Pandey ${ }^{2}$, Rakhee Gogoi ${ }^{3}$, Nagender Solanki ${ }^{2}$, Renu Madan ${ }^{4}$, \\ Anupam Mondal ${ }^{5}$, Shruti Dogra ${ }^{4}$, Pradeep Thapa ${ }^{5}$
}

${ }^{1}$ Department of Endocrinology, Venkateshwar Hospitals, Dwarka, New Delhi, India

${ }^{2}$ Department of Orthopaedics, Venkateshwar Hospitals, Dwarka, New Delhi, India

${ }^{3}$ Department of Radiology, Venkateshwar Hospitals, Dwarka, New Delhi, India

${ }^{4}$ Department of Pathology, Venkateshwar Hospitals, Dwarka, New Delhi, India

${ }^{5}$ Department of Nuclear Medicine, Venkateshwar Hospitals, Dwarka, New Delhi, India

\begin{abstract}
Background: Tumour-induced osteomalacia (TIO) are extremely rare paraneoplastic syndromes with less than 300 reported cases. This report highlights the pitfalls and challenges in diagnosing and localising TIO in patients with refractory and resistant osteomalacia.

Material and methods: A 41-year-old gentleman with a four-year history of musculoskeletal weakness and pathologic fractures presented in a wheelchair-bound incapacitated state of one-year duration. Investigations were significant for severe hypophosphataemia, severe phosphaturia, normal serum calcium, reduced 1,25-dihydroxy vitamin-D, elevated ALP, elevated intact parathyroid hormone (iPTH), and pseudo-fractures involving the pelvis and bilateral femur. Whole body MRI and ${ }^{99 \mathrm{~m}} \mathrm{Tc}$ methylene diphosphonate bone-scan were also normal. Whole body FDG-PET scan involving all four limbs revealed a small FDG avid lesion at the lateral border of the lower end of the left femur (SUV max 3.9), which was well characterised on three-dimensional CT reconstruction. Plasma C-terminal fibroblast growth factor (FGF)-23 was $698 \mathrm{RU} / \mathrm{mL}$ (normal < $150 \mathrm{RU} / \mathrm{ml}$ ). Wide surgical excision of the tumour was done. Histopathology confirmed mesenchymal tumour of mixed connective tissue variant. Serum phosphorous normalised on post-surgery day 1 . High-dose oral calcium and vitamin-D was continued. FGF-23 normalised post-surgery (73 RU/ml). Physical strength improved significantly and now he is able to walk independently.

Conclusions: TIO is frequently confused with normocalcaemic hyperparathyroidism and vitamin-D resistant rickets/osteomalacia, which increases patient morbidity. Imaging for tumour localisation should involve the whole body, from the head to the tip of the digits, because these tumours are notoriously small and frequently involve digits of the hands and feet. Complete surgical removal of the localised tumour is key to good clinical outcomes. (Endokrynol Pol 2018; 69 (2): 205-210)

Key words: hypophosphataemic osteomalacia, tumour induced osteomalacia, phosphatonin, paraneoplastic, fibroblast growth factor

\section{Streszczenie}

Wstęp: Osteomalacja wywołana obecnością guza (tumor-induced osteomalacia, TIO) to niezwykle rzadki zespół paraneoplastyczny. Opisano dotąd tylko niecałe 300 przypadków tego zespołu. W niniejszej pracy zwrócono uwagę na błędy i problemy przy diagnozowaniu i lokalizowaniu TIO u chorych z oporną na leczenie osteomalacją.

Materiał i metody: W pracy przedstawiono przypadek chorego w wieku 41 lat, u którego od 4 lat występowały złamania patologiczne i osłabienie układu mięśniowo-szkieletowego prowadzące do niepełnosprawności, w wyniku czego chory od roku korzystał z wózka inwalidzkiego. W badaniach stwierdzono ciężką hipofosfatemię, ciężką fosfaturię, prawidłowe stężenie wapnia w surowicy, zmniejszone stężenie witaminy 1,25-dihydroksy D, podwyższoną aktywność fosfatazy zasadowej, zwiększone stężenie parathormonu w postaci całkowitej cząsteczki (intact parathyroid hormone, iPTH) oraz złamania rzekome w obrębie miednicy i obu kości udowych. W badaniu MRI całego ciała oraz scyntygrafii kości z użyciem difosforanu metylenu znakowanego technetem ${ }^{99 m} \mathrm{~T} c$ nie stwierdzono nieprawidłowości. W obrazie badania FDG-PET obejmującego wszystkie 4 kończyny zauważono niewielką zmianę o zwiększonym wychwycie FDG na bocznej powierzchni dolnego końca lewej kości udowej (SUV maks. 3,9), którą dobrze scharakteryzowano w trójwymiarowej rekonstrukcji CT. Stężenie C-końcowego peptydu czynnika wzrostu fibroblastów-23 (fibroblast growth factor-23, FGF-23) wynosiło 698 RU/ml (norma $<150 \mathrm{RU} / \mathrm{ml}$ ). Guz usunięto chirurgicznie z szerokim marginesem. W badaniu histopatologicznym potwierdzono rozpoznanie guza mezenchymalnego - wariant mieszanej tkanki łącznej. W pierwszym dniu po operacji stwierdzono normalizację stężenia fosforu w surowicy. Kontynuowano stosowanie dużych doustnych dawek wapnia i witaminy D. Również stężenie FGF-23 unormowało się po zabiegu (73 RU/ml). U chorego zwiększyła się siła fizycznej i obecnie może on chodzić samodzielnie.
\end{abstract}


Wnioski: Osteomalacja wywołana obecnością guza (TIO) jest często mylona z normokalcemiczną nadczynnością przytarczyc i krzywicą/ osteomalacją oporną na leczenie witaminą D, co powoduje zwiększoną chorobowość pacjentów. Badania obrazowe w celu zlokalizowania guza powinny obejmować całe ciało od czubka głowy po palce u stóp, ponieważ guzy te są zwykle małe i często umiejscawiają się w obrębie palców dłoni i stóp. Całkowite chirurgiczne usunięcie guza warunkuje uzyskanie dobrego efektu leczenia. (Endokrynol Pol 2018; 69 (2): 205210)

Słowa kluczowe: osteomalacja hipofosfatemiczna, osteomalacja indukowana nowotworem, fosfatonina, paraneoplastyka, czynnik wzrostu fibroblastów

\section{Introduction}

Tumour-induced osteomalacia (TIO)/ oncogenic osteomalacia are extremely rare paraneoplastic syndromes, characterised by phosphatonin-induced acquired renal phosphate wasting, resulting in musculoskeletal weakness, increased skeletal fragility, and morbidity [1]. Phosphatonins are small peptides (fibroblast growth factor [FGF]-23, FGF-7, secreted frizzle-related protein 4 [SFRP4], matrix extracellular phosphoglycoprotein [MEPE]) secreted from small, slow growing tumours, resulting in phosphaturia [2, 3]. Diagnosis of TIO remains a challenge and is often delayed due to their rarity and non-specific features, resulting in increased morbidity and mortality [1]. This report highlights the challenges in diagnosing and localising the culprit lesion in a patient with $\mathrm{TIO}$, and also highlights the treatment outcomes.

\section{Patient report}

A 41-year-old gentleman presented with progressive weakness of both legs for the previous four years without any improvement in symptoms in spite of chronic high-dose vitamin-D and calcium supplementation. He had severe bone pains necessitating chronic NSAIDs use for the previous two years. One year ago he fractured the right neck of the femur following a minor fall at home, necessitating surgical correction and fixation. He was seen at our institute in an incapacitated, wheelchair-bound state, which had lasted for one year. Family history was unremarkable. Examination was significant for severe proximal lower limb weakness and wasting. Biochemical evaluation was significant for severe hypophosphataemia, severe phosphaturia (low transport maximum of phosphate per glomerular filtration rate [TmP-GFR]), with normal serum calcium, reduced 1,25-dihydroxy vitamin-D, mildly elevated ALP, and mildly elevated intact parathyroid hormone (iPTH) (Table I). Skeletal imaging of whole body was significant for pseudo-fractures involving the pelvis and bilateral femur. He was started on oral high-dose phosphorous ( $2.5 \mathrm{~g}$ /day sodium dihydrogen phosphate; five tablets of phosphate Sandoz 500 mg per day; Novartis, New South Wales, Australia) and calcitriol replacement ( $1 \mathrm{mcg} /$ day; four capsules of Rocaltrol per day; Roche,
Table I. Biochemical profile of patients at initial presentation, post-surgical removal of tumour, and following octreotide therapy for tumour-induced osteomalacia

Tabela I. Profil biochemiczny chorego w momencie zgtoszenia się do szpitala, po chirurgicznym usunięcia guza i po leczeniu oktreotydem $w$ zwiqzku $z$ osteomalacja spowodowanq obecnościq guza

\begin{tabular}{llll}
\hline \multirow{2}{*}{ Parameter } & Baseline & \multicolumn{2}{c}{ Post-operative } \\
\cline { 3 - 4 } & (pre-operative) & Day 1 & Day 21 \\
\hline Calcium [mg/dl] (8.6-10.8) & 8.7 & 9.43 & 8.7 \\
\hline Phosphorus [mg/dl] (3.5-5) & 1.0 & 3.3 & 4.3 \\
\hline ALP [U/L] (38-136) & 151 & 203 & 177 \\
\hline Albumin [mg/dl] (3.5-4.2) & 4.3 & 4.2 & 4.4 \\
\hline 250HD [ng/ml] (30-100) & 44.3 & - & 69 \\
\hline iPTH [pg/ml] (7-65) & 93 & - & - \\
\hline Creatinine [mg/dl] & 0.9 & 0.9 & 0.8 \\
\hline TmP-GFR [mg/dl] (2.8-4.4) & 0.982 & - & - \\
\hline 1,25 (0H)2 Vitamin-D & 34 & - & - \\
[pmol/L] (48-108) & & & \\
\hline Dose of Calcium [g/d] & - & 1.5 & 2 \\
\hline Dose of phosphate [g/d] & 2.5 & STOPPED & STOPPED \\
\hline Dose of calcitriol [mg/d] & 1.0 & 1.0 & 0.5 \\
\hline
\end{tabular}

Values in parentheses indicate normal range; ALP — alkaline phosphatase; 250HD - 25-hydroxyvitamin-D; iPTH — intact parathyroid hormone; TmP-GFR - transport maximum of phosphate per glomerular filtration rate; Chemiluminescent microparticle immunoassay (VITROS ${ }^{\circledR}$ ECiO Immunodiagnostic System, Johnson \& Johnson, USA) was used for iPTH estimation (assay sensitivity $3.4 \mathrm{pg} / \mathrm{ml}$; range: $3.4-5000 \mathrm{pg} / \mathrm{ml}$; intra-assay and inter-assay coefficient of variation $2.1 \%$ and $4.7 \%$, respectively); Calcium, phosphate, albumin, and creatinine were assayed using the automated Vitros ®5, 1FS clinical chemistry analyser (Johnson \& Johnson, USA)

Ontario, Canada). Tumour-induced osteomalacia (TIO) was suspected. Whole-body MRI was normal. Whole-body ${ }^{99 \mathrm{~m}} \mathrm{Tc}$ methylene diphosphonate (MDP) bone-scan was also normal. Subsequently, a careful review of whole-body 18(F)-FDG-PET scan involving all four limbs to the tips of the digits revealed a small FDG avid lesion at the lateral border of the lower end of left femur. CT scan with three-dimensional CT reconstruction helped in better anatomic localisation of this extremely small lesion of $1 \mathrm{~cm}$ diameter at the lower end of the left femur (Figure 1). Plasma C-terminal fibroblast growth factor (FGF)-23 using enzyme-linked immunosorbent assay (ELISA) was 


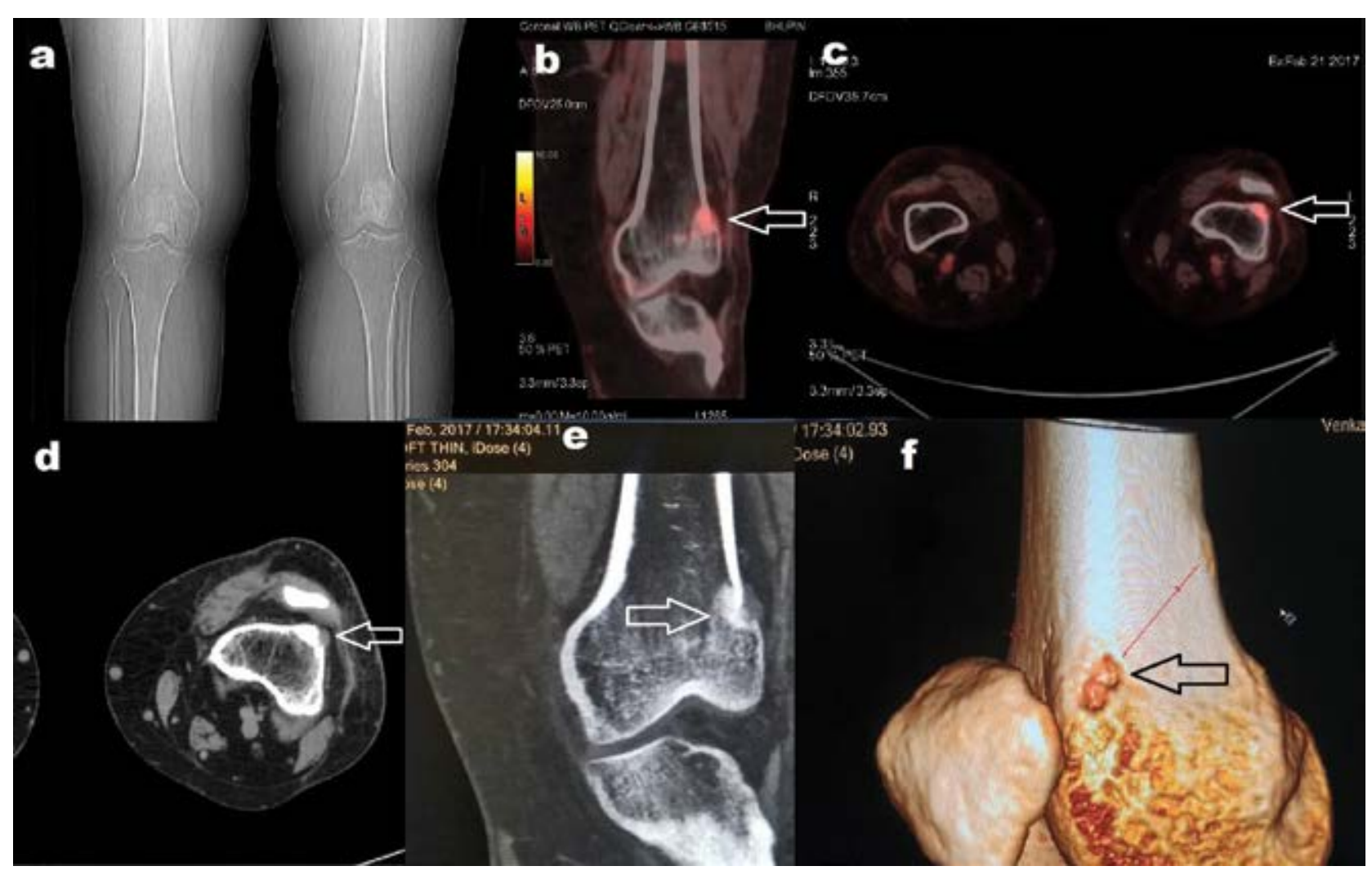

Figure 1A. Normal X-ray of bilateral knee joints and lower end of femur; B. Fluorodeoxyglucose (FDG) positron emission tomography (PET) with superimposed CT showing increased FDG uptake in the lateral border of lower end of left femur; C. Coronal cuts of lower end of femurs showing increased FDG uptake along the lateral border of left femur localising the culprit tumour; D. Thin-cut CT (coronal sections) showing the culprit FDG avid tumour having bony and soft tissue component ( $<1 \mathrm{~cm}$ diameter); E. Thin-cut CT left knee reconstruction showing the culprit lesion having bony and soft tissue component; $\mathbf{F}$. Three-dimensional reconstruction showing the culprit lesion responsible for tumour-induced osteomalacia at the lower end of the left femur

Rycina 1A. Prawidtowy obraz badania RTG obu stawów kolanowych oraz dolnego odcinka kości udowych; B. Pozytonowa tomografia emisyjna (positron emission tomography, PET) z zastosowaniem fluorodeoksyglukozy (fluoro-deoxy-glucose, FDG) w połaczeniu z tomografia komputerowa (computed tomography, CT) — widoczny zwiększony wychwyt FDG w bocznej części dolnego odcinka kości udowej lewej; C. Przekroje czołowe dolnego odcinka kości udowej lewej z uwidocznionym zwiększonym wychwytem FDG wzdtuż bocznej powierzchni kości udowej lewej odpowiadającym lokalizacji guza powodującego objawy; D. Tomografia komputerowa (cienkie warstwy, przekroje czołowe) uwidacznia guz wychwytujaccy FDG, złożony z tkanki kostnej i tkanek miękkich (średnica $<1 \mathrm{~cm}$ ); E. Rekonstrukcja CT stawu kolanowego lewego (cienkie warstwy) uwidacznia guz złożony z tkanki kostnej i tkanek miękkich; F. Rekonstrukcja trójwymiarowa pokazująca guz powodujący osteomalację w dolnym odcinku kości udowej lewej

$698 \mathrm{RU} / \mathrm{mL}$ (normal < $150 \mathrm{RU} / \mathrm{ml}$; assay sensitivity $1.5 \mathrm{RU} / \mathrm{mL}$, intra-assay and inter-assay coefficient of variation $2.4 \%$ and $4.7 \%$, respectively; Immutopics, California, USA), which supported the diagnosis. Wide surgical excision of the tumour was done (Figure 2). Histopathology confirmed a mesenchymal tumour of mixed connective tissue variant (Figure 3). On postsurgery day 1 his serum phosphorus improved to 3.3 $\mathrm{mg} / \mathrm{dl}$. Phosphate replacement was stopped. High-dose oral calcium (calcium carbonate $2 \mathrm{~g} /$ day), vitamin-D and calcitriol supplementation was continued. FGF23 levels normalised post-surgery $(73 \mathrm{RU} / \mathrm{ml})$. His last evaluated (three weeks post-surgery) serum phosphorous was $4.3 \mathrm{mg} / \mathrm{dl}$, his physical strength improved significantly, and he was able to walk independently.

\section{Discussion}

The diagnostic challenge of TIO is highlighted by the fact that when all the reported TIO patients were reviewed up to 2012, the average time from onset of symptoms to a confirmed biochemical diagnosis often exceeded 2.5 years, and definitive treatment is often delayed by five years due to challenges in anatomic localisation of the culprit tumour [4].

TIO has no sex predilection and most commonly occur in the age groups of 30-40 years [3, 4]. TIO usually presents as diffuse metabolic bone disease, musculoskeletal weakness, and skeletal fragility, resistant to conventional treatment (calcium and vitamin supplementation). The typical biochemical picture associated 


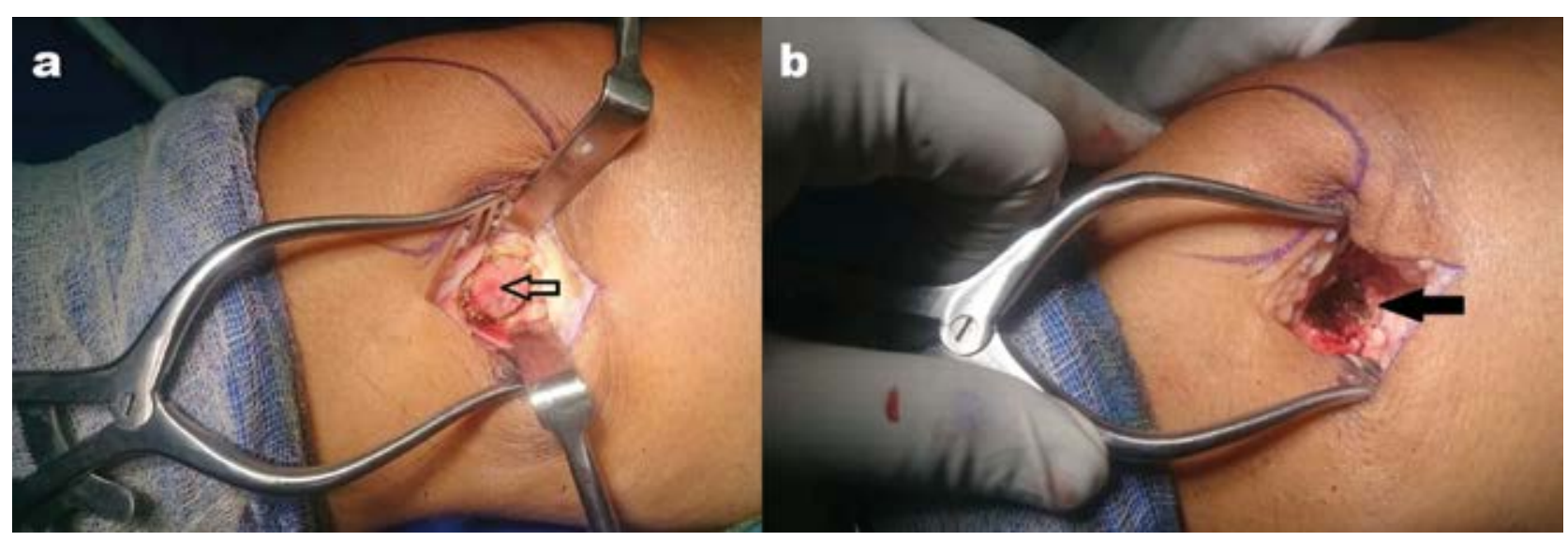

Figure 2A. Intra-operative image of the tumour (hollow black arrow) after surgical dissection; B. Intra-operative image after wide surgical resection of the tumour at the lower end of the left femur (solid black arrow)

Rycina 2A. Śródoperacyjne zdjęcie guza (strzałka niewypetniona z czarnym obrysem) po resekcji chirurgicznej; B. Zdjęcie śródoperacyjne wykonane po szerokiej resekcji guza umiejscowionego w dolnym odcinku kości udowej lewej (czarna strzałka)

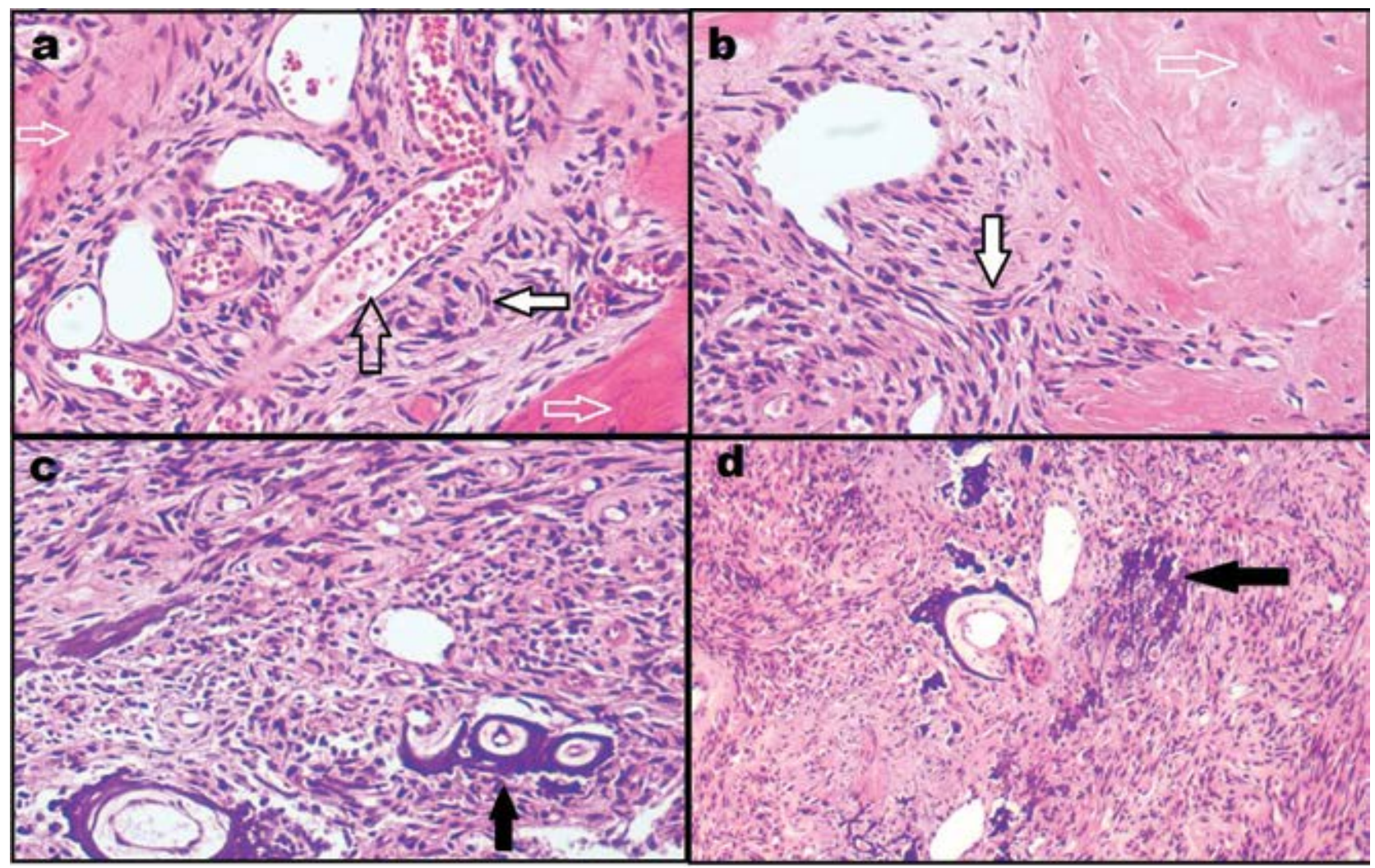

Figure 3A. Haematoxylin \& Eosin (HEE)-stained section of resected tumour (high power) showing proliferating spindle cells amidst the bony spicules (hollow white arrow) and blood vessels (hollow black arrow). Few of the proliferating spindle cells can be seen arranged in whorls (solid white arrow with black borders); B. Proliferating spindle cells can be seen, without any evidence of cellular atypia (solid white arrow with black borders); adjacent bony spicules and matrix also seen (hollow white arrow); C. HEE stained section (high power) showing spindle cell mesenchymal neoplasm with variable cellularity having areas of grungy calcification (solid black arrow), with chondromyxoid background; D: HEE stained section (low power) showing proliferating spindle cells having areas of grungy calcification (solid black arrow)

Rycina 3A. Preparat histopatologiczny wyciętego guza (barwienie hematoksylina i eozyna [HE], duże powiększenie) z proliferującymi komórkami wrzecionowatymi między iglicami kostnymi (niewypetniona biała strzałka). Można zauważyć komórki wrzecionowate ułożone w kształt spirali (biała strzałka z czarnym obrysem); B. Widoczne proliferujące komórki wrzecionowate bez cech atypii (biata strzałka z czarnym obrysem) oraz sąsiadujące z nimi iglice kostne i macierz (niewypetniona biała strzałka); C. Preparat barwiony HE (duże powiększenie) pokazujący nowotwór wrzecionowatokomórkowy pochodzenia mezenchymalnego o zróżnicowanej liczbie i wielkości komórek, z obszarami zwapnień (grungy calcification) (czarna strzatka) na tle utkania chrzęstno-śluzowego; D. Preparat barwiony HE (małe powiększenie) przedstawiający proliferujące komórki wrzecionowate z obszarami zwapnień (grungy calcification) (czarna strzałka) 
with TIO is normocalcaemia, hypophosphataemia, normal serum 25-hydroxy-vitamin-D (25OHD), and mildly raised serum ALP and iPTH, which often leads to a misdiagnosis of normocalcaemic hyperparathyroidism [5]. Serum 1,25-dihydroxy-vitamin-D (1,25OH2D) is not routinely tested in patients with metabolic bone disorders. In TIO serum 1,25OH2D is usually low, due to the inactivation of 1-alpha-hydroxylase enzyme in the kidneys by the increased circulating levels of phosphatonins (FGF-23 most commonly) [6]. Normal serum $25 \mathrm{OHD}$ with low $1,25 \mathrm{OH} 2 \mathrm{D}$ may lead to a misdiagnosis of vitamin-D resistant rickets/osteomalacia. Hence these patients often end up receiving high doses of calcium and vitamin-D replacement (cholecalciferol and/or calcitriol) without any clinical benefit. It is ironic to consider that this misconception has persisted since the first report of TIO in 1947, in which osteomalacia and vitamin-D resistance was diagnosed in a 15-yearold girl, and the entire disease presentation was not attributed to the femoral tumour in her [3]. It must, however, be realised that the entire clinical and biochemical manifestation can be explained by increased circulating levels of phosphatonins, which is responsible for phosphaturia, hypophosphataemia, and low $1,25 \mathrm{OH} 2 \mathrm{D}$ levels with associated mild increase in ALP and $\mathrm{iPTH}[6,7]$.

A high degree of clinical suspicion is key to diagnosis. Lack of family history of similar illness, a higher age of disease onset, and a shorter history of disease duration are points against familial hypophosphataemic osteomalacia (FHO), which also has a similar skeletal and biochemical picture [8]. FHO can be either X-linked dominant hypophosphataemia (XLH), autosomal dominant hypophosphataemic rickets (ADHR), and autosomal recessive hypophosphataemic rickets (ARHR), which are believed to be due to mutations in the phosphate-regulating endopeptidase gene (PHEX) gene, FGF-23 gene, and dentin matrix acidic phosphoprotein1 gene (DMP1) gene, respectively [9] Depending on the underlying mutation, $\mathrm{FHO}$ is associated with either increased endogenous phosphatonin production, or decreased phosphatonin degradation and excretion from the body resulting in the manifestation of hypophosphataemic osteomalacia [8, 9]. For unknown reasons, muscle weakness, especially lower limb (as in our patient), is not a feature of XLH and ADHR [1]. Serum phosphatonins (FGF-23) are elevated both in TIO and FHO $[8,9]$.

Localisation of the culprit lesion is the next major step once the biochemical diagnosis of TIO is established. This is because isolated chronic medical therapy in general is associated with poor outcomes. Medical therapy consists of high-dose oral phosphorous replacement with cholecalciferol and calcitriol supplementa- tion, aiming to keep serum phosphorous in the low normal range. However, high-dose oral phosphorous replacement is often poorly tolerated, associated with gastrointestinal symptoms like nausea, diarrhoea, abdominal pain, and dyspepsia, along with increased risks of phosphorous-induced secondary hyperparathyroidism (increased serum phosphate is stimulus for PTH release, which worsens phosphaturia, thus limiting its use), hypercalciuria, and renal stone formation.

Surgical removal of the culprit tumour, in contrast, is associated with good clinical outcomes and normalisation of serum phosphorous in more than $88 \%$ of patients, as in a series of 40 patients from China [10]. Recurrence is uncommon $(<5 \%)$, except when the surgical resection is not complete or if the tumour is malignant, which is extremely rare $[5,10]$. Radiotherapy $(45-50 \mathrm{~Gy})$ has been used with mixed outcomes in patients with surgically incurable/residual/ metastatic disease [5]. Somatostatin analogues (octreotide, sandostatin-LAR), monoclonal antibodies against FGF-23, and peptide receptor radionuclide therapy are some of the experimental therapies that have been tried in patients with surgically incurable disease, with mixed outcomes [1, 11, 12]. Expression of somatostatin receptors (SSTRs) especially SSTR2 by these tumours forms the rationale for their use in the diagnosis and treatment of TIO [1].

A large variety of imaging modalities have been used for localising the culprit lesion in TIO, ranging from whole-body MRI and computed tomography (CT) to functional nuclear imaging (MDP bone scans, FDG-PET scans, ${ }^{111} \mathrm{In}$-pentetreotide scintigraphy/octreotide scan, and DOTANOC-PET scans). Nuclear imaging has better sensitivity and specificity in tumour localisation as compared to conventional CT/MRI. It is important to highlight that whatever imaging modality is used for tumour localisation, it is important to painstakingly scan the whole body from the head to tip of the digits in the hands and feet because these tumours are notoriously small and diverse in localisation, and can frequently involve the digits of hands and feet [13]. In fact, 95\% of all TIOs have been reported in extremities, and the remaining $5 \%$ were from the head and neck region [14]. Combining different imaging techniques and selective venous FGF-23 sampling has been found to be useful in localising small and otherwise occult tumours $[15,16]$. Recent reports have suggested SSTR based nuclear imaging to have a good sensitivity and specificity in localising TIO. 99mTc-HYNIC-TOC scan has been demonstrated to have $86.3 \%$ sensitivity $(69 / 80 \mathrm{TIO})$ and $99.1 \%$ specificity (ruled out 102/103 individuals) in localising TIO [17]. ${ }^{68} \mathrm{Ga}$-DOTATATE PET/computed tomography (CT) has also been found to useful in localising TIO lesions missed by conventional imaging [18]. From a histopathology point of view, $70-80 \%$ of TIOs are due 
to mixed connective tissue (MCT) variant of mesenchymal tumour, as was the case in our patient [19]. 53\% of these tumours occur within bones, $45 \%$ in soft tissue, and $3 \%$ in the skin $[5,19]$. Malignant MCTs are extremely rare, with only three cases reported to date [20,21].

To conclude, it may be said that TIO is a paraneoplastic syndrome caused by the phosphaturic hormone FGF-23, which results in refractory hypophosphataemia, osteomalacia, and musculoskeletal weakness, all of which are completely reversible by surgical removal of the culprit neoplasm.

\section{Authors' contribution}

The patient was admitted under the primary care of $\mathrm{DD}$, who did the diagnosis of TIO and planned the treatment regimen. NS and RKP carried out surgical removal of the culprit tumour. Biochemical work up and histopathological evaluation of the resected specimen was done by RM and SD. Radiological evaluation of the patient and CT localisation of the tumour was done by RG. Bone scans and whole body FDG PET scan and interpretation was done by AM and PT, who helped in localising the small mesenchymal tumour.

\section{Reference}

1. Kulshreshtha B, Sharma LK, Sharma N, et al. Octreotide and Cinacalcet Have Limited Role in Managing Surgically Incurable Tumor Induced Osteomalacia. Acta Endo (Buc). 2015; 11(4); doi: 10.4183/aeb.2015.517.

2. Jan de Beur SM, Streeten EA, Civelek AC, et al. Localisation of mesenchymal tumours by somatostatin receptor imaging. Lancet. 2002; 359(9308): 761-763, indexed in Pubmed: 11888589.

3. McCance RA. Osteomalacia with Looser's nodes (Milkman's syndrome) due to a raised resistance to vitamin $D$ acquired about the age of 15 years. Q J Med. 1947; 16(1): 33-46, indexed in Pubmed: 20296654.

4. Jiang $\mathrm{Y}, \mathrm{Xia} \mathrm{Wb}$, Xing $\mathrm{Xp}$, et al. Tumor-induced osteomalacia: an important cause of adult-onset hypophosphatemic osteomalacia in China: Report of 39 cases and review of the literature. J Bone Miner Res. 2012; 27(9): 1967-1975, doi: 10.1002/jbmr.1642, indexed in Pubmed: 22532501.

5. Hautmann AH, Schroeder J, Wild P, et al. Tumor-Induced Osteomalacia: Increased Level of FGF-23 in a Patient with a Phosphaturic Mesenchymal Tumor at the Tibia Expressing Periostin. Case Rep Endocrinol. 2014; 2014: 729387, doi: 10.1155/2014/729387, indexed in Pubmed: 25221676.

6. Khosravi A, Cutler CM, Kelly MH, et al. Determination of the elimination half-life of fibroblast growth factor-23. J Clin Endocrinol Metab. 2007; 92(6): 2374-2377, doi: 10.1210/jc.2006-2865, indexed in Pubmed: 17374707.
7. Shimizu Y, Tada Y, Yamauchi M, et al. Hypophosphatemia induced by intravenous administration of saccharated ferric oxide: another form of FGF23-related hypophosphatemia. Bone. 2009; 45(4): 814-816, doi: 10.1016/j.bone.2009.06.017, indexed in Pubmed: 19555782.

8. Endo I, Endo I, Fukumoto S, et al. Nationwide survey of fibroblast growth factor 23 (FGF23)-related hypophosphatemic diseases in Japan: prevalence, biochemical data and treatment. Endocr J. 2015; 62(9): 811-816, doi: 10.1507/endocrj.EJ15-0275, indexed in Pubmed: 26135520.

9. Yue H, Yu Jb, He Jw, et al. Identification of two novel mutations in the PHEX gene in Chinese patients with hypophosphatemic rickets/osteomalacia. PLoS One. 2014; 9(5): e97830, doi: 10.1371/journal.pone.0097830, indexed in Pubmed: 24836714.

10. Sun $\mathrm{Zj}$, Jin J, Oiu Gx, et al. Surgical treatment of tumor-induced osteomalacia: a retrospective review of 40 cases with extremity tumors. BMC Musculoskelet Disord. 2015; 16: 43, doi: 10.1186/s12891-015-0496-3, indexed in Pubmed: 25879543.

11. Fukumoto S. Anti-fibroblast growth factor 23 antibody therapy. Curr Opin Nephrol Hypertens. 2014; 23(4): 346-351, doi: 10.1097/01. mnh.0000447012.98357.da, indexed in Pubmed: 24848934.

12. Basu S, Fargose P. 177Lu-DOTATATE PRRT in Recurrent Skull-Base Phosphaturic Mesenchymal Tumor Causing Osteomalacia: A Potential Application of PRRT Beyond Neuroendocrine Tumors. J Nucl Med Technol. 2016; 44(4): 248-250, doi: 10.2967/jnmt.116.177873, indexed in Pubmed: 27634982

13. Kaneuchi Y, Hakozaki M, Yamada H, et al. Missed causative tumors in diagnosing tumor-induced osteomalacia with (18)F-FDG PET/ /CT: a potential pitfall of standard-field imaging. Hell J Nucl Med. 2016; 19(1): 46-48, doi: 10.1967/s002449910337, indexed in Pubmed: 26929940.

14. Qari H, Hamao-Sakamoto A, Fuselier C, et al. Phosphaturic Mesenchymal Tumor: 2 New Oral Cases and Review of 53 Cases in the Head and Neck. Head Neck Pathol. 2016; 10(2): 192-200, doi: 10.1007/s12105-0150668-3, indexed in Pubmed: 26577211.

15. Clifton-Bligh RJ, Hofman MS, Duncan E, et al. Improving diagnosis of tumor-induced osteomalacia with Gallium-68 DOTATATE PET/CT. J Clin Endocrinol Metab. 2013; 98(2): 687-694, doi: 10.1210/jc.2012-3642, indexed in Pubmed: 23295468.

16. Ito N, Shimizu Y, Suzuki H, et al. Clinical utility of systemic venous sampling of FGF23 for identifying tumours responsible for tumour-induced osteomalacia. J Intern Med. 2010; 268(4): 390-394, doi: 10.1111/j.13652796.2010.02262.x, indexed in Pubmed: 20698924.

17. Jing $\mathrm{H}$, Li F, Zhuang $\mathrm{H}$, et al. Effective detection of the tumors causing osteomalacia using [Tc-99m]-HYNIC-octreotide (99mTc-HYNIC-TOC) whole body scan. Eur J Radiol. 2013; 82(11): 2028-2034, doi: 10.1016/j. ejrad.2013.04.006, indexed in Pubmed: 23721625.

18. El-Maouche D, Sadowski SM, Papadakis GZ, et al. 68Ga-DOTATATE for Tumor Localization in Tumor-Induced Osteomalacia. J Clin Endocrinol Metab. 2016; 101(10): 3575-3581, doi: 10.1210/jc.2016-2052, indexed in Pubmed: 27533306

19. Jan de Beur SM. Tumor-induced osteomalacia. JAMA. 2005; 294(10): 1260-1267, doi: 10.1001/jama.294.10.1260, indexed in Pubmed: 16160135.

20. Folpe AL, Fanburg-Smith JC, Billings SD, et al. Most osteomalaciaassociated mesenchymal tumors are a single histopathologic entity: an analysis of 32 cases and a comprehensive review of the literature. Am J Surg Pathol. 2004; 28(1): 1-30, indexed in Pubmed: 14707860.

21. Leaf DE, Pereira RC, Bazari H, et al. Oncogenic osteomalacia due to FGF23-expressing colon adenocarcinoma. J Clin Endocrinol Metab. 2013; 98(3): 887-891, doi: 10.1210/jc.2012-3473, indexed in Pubmed: 23393166. 